\title{
Leaves Composting Process and the Influence of Rumen Content and Bran Addition
}

\author{
Mochamad Arief Budihardjo ${ }^{1, *}$, Endro Sutrisno ${ }^{1}$, Purwono $^{1}$ and Maulia Fatimah $^{1}$ \\ ${ }^{1}$ Department of Environmental Engineering, Universitas Diponegoro, Jl.Prof.H.Soedarto, S.H. \\ Tembalang, Semarang, Indonesia
}

\begin{abstract}
Leaves on the Diponegoro University campus were sent to the university's solid waste facility for composting. A modification of the normal composting process was implemented to speed up the process. In this study, the content of cattle rumens and rice bran were added to accelerate the composting process. Three samples with different composition were prepared (sample code: L, L-R, and L-B). Sample L contained leaves only, sample L-R comprised of leaves with rumen content added and sample L-B consisted of leaves with the addition of rice bran. The results indicated that a maximum temperature of $60.2^{\circ} \mathrm{C}$ was reached in the L-B sample, while the temperature of compost and L-R was about $30^{\circ} \mathrm{C}$. The lowest $\mathrm{pH}$ was 6.76 found on the L sample, with sample L-B and L-R having $\mathrm{pH}$ of 6.7 and 6.9, respectively. The quality of the mature compost of all variation was about the same, but the compost in sample L$\mathrm{B}$ produced the highest $\mathrm{C} / \mathrm{N}$ ratio of the three composts, about $20 \%$ higher.
\end{abstract}

\section{Introduction}

The processing of solid waste contributes significantly to environmental pollution. In some developing countries, the concepts of solid waste management practise, such as reuse and recycling, has not been implemented effectively [1]. To date, the handling of solid waste comprises primarily of the collection of waste and its transfer to landfill where it is dumped. Without any reduction, reusing or recycling practices in place, the amount of solid waste to be sent to landfill has increased over time [2,3].

The University is one of the biggest contributors to municipal waste due to its various activities, such as administration, teaching and cleaning. Solid waste that is produced by Diponegoro University contains a significant amount of leaves, about $40 \%$ of the total waste by weight. The leaves are sent to the waste facilities in the Diponegoro University area to be composted. However, the composting process of leaves takes time and the land availability is limited [4]. Therefore, a modification of the composting process with the purpose to accelerate the process, by adding the rumen contents of cattle and rice bran, would have great advantages. The ruminal content of cattle was chosen as it is rich with microbes [5], while rice bran is commonly used in Asian countries as a bulking agent in the composting process [6].

\footnotetext{
* Corresponding author: m.budihardjo@ft.undip.ac.id
} 
Therefore, this study investigates the effect of the addition of these two components on the process of composting leaves. The composting experiment was conducted over 30 days. Temperature and $\mathrm{pH}$ of the composting piles were measured regularly, in order to understand the influence of rice bran and the content of cattle rumen on the composting process.

\section{Methods}

In order to conduct the experiment, three compost samples with different composition were prepared (sample codes: L, L-R, and L-B). Sample L contained leaf waste only, sample L-R comprised of leaves with rumen content added and sample L-B consisted of leaves with the addition of rice bran. Cow ruminal content was collected from the local slaughter house and rice bran was supplied by the local rice mill.

The conventional composting process of leaves $(\mathrm{L})$ is compared with samples L-R and L-B. Temperature and $\mathrm{pH}$ of all compost piles were measured daily. The composting was done using the MacDonald method which uses boxes and an aerobic system. Watering was done regularly to keep the moisture content of compost piles constant. After 30 days the compost products were analyzed for parameters such as physical appearance, organic content, total nitrogen $(\mathrm{N}), \mathrm{C} / \mathrm{N}$ ratio, total phosphorus $(\mathrm{P})$, total potassium $(\mathrm{K})$ and water content.

\section{Results and Discussion}

\subsection{Temperature}

The temperature was measured on a daily basis during the composting process. Figure 1 shows the temperature fluctuation during the composting period. From all three samples there was only one sample that experienced the ideal thermophilic phase, sample L-B. The thermophilic phase occurred between the $2 \mathrm{nd}$ and 5 th day. The maximum temperature of samples L and L-R during the composting period was about $30^{\circ} \mathrm{C}$.

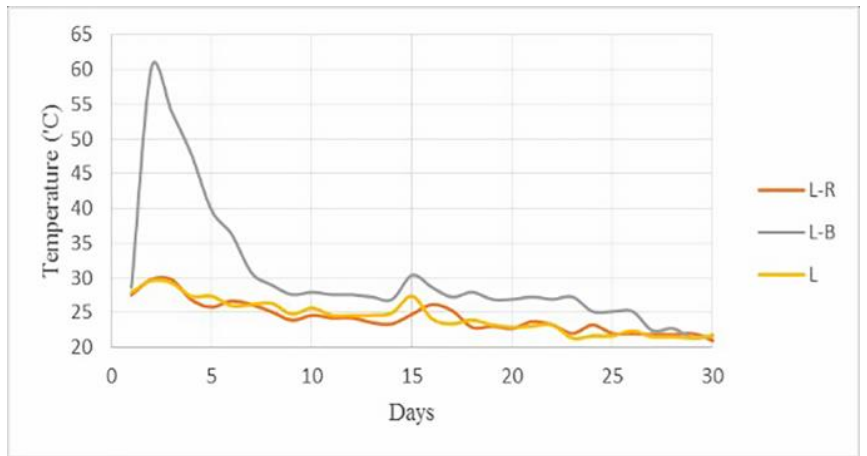

Fig 1. Temperature changes during composting

The presence of the rice bran caused L-B variation reach thermophilic conditions. Rice bran functioned as a nutrient for composting bacteria which influenced the activities of the bacteria in the processing of organic materials during composting, thus accelerating the materials' decomposition. Whereas the samples L-R and L did not reach the thermophilic temperature, with temperatures ranging from about $23^{\circ} \mathrm{C}$ to $30^{\circ} \mathrm{C}$ during the composting process. 


\subsection{PH}

A pH measurement of the compost piles was performed on a daily basis. The results of the $\mathrm{pH}$ monitoring for each sample is shown in Figure 2. At the beginning of the decomposition process, the $\mathrm{pH}$ of each compost sample dropped during the thermophilic phase, indicating high microbe activity in decomposing the organic material. The $\mathrm{pH}$ gradually increased after the maximum temperature was reached and gradually became neutral. The changes in $\mathrm{pH}$ could be due to the microbial activity, i.e. various bacteria and fungus require different acid environments to decompose organic matter. This $\mathrm{pH}$ decrease was consistent with the increase of compost temperature in the thermophilic phase.

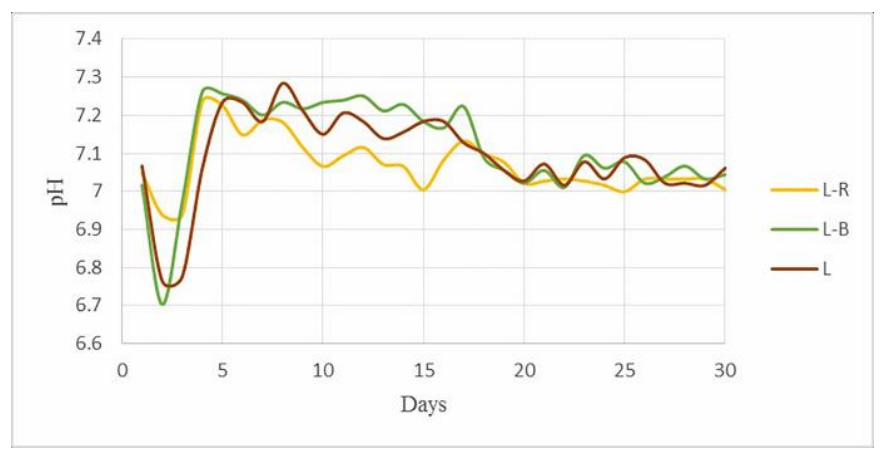

Fig. 2. Average $\mathrm{pH}$ in compost pile

After the thermophilic phase, the $\mathrm{pH}$ gradually increases to produce weak basic conditions. The activity of the thermophilic bacteria creates ammonia and nitrogen gases, causing the rise $\mathrm{pH}$. The highest $\mathrm{pH}$ recorded was between days 4 and 8 for all compost samples. In the next phase, a nitrification process occurs where the nitrogen is found in the form of nitrate. This will gradually decrease the $\mathrm{pH}$ to a constant $\mathrm{pH}$, indicating composting maturity. The $\mathrm{pH}$ for all the compost samples were within the optimum range for composting (pH5 - 8) [7].

\subsection{Mature Compost}

The physical appearance of the mature compost sample appeared to be similar. The compost did not have an unpleasant odour but smelt like soil. The colour of compost was brownish black, similar to soil. Table 1 shows the quality of the compost product for each sample. Overall, the final compost for samples were similar in quality. The C-organic content ranged from $3.42 \%$ to $6.9 \%$ with total N $0.18 \%$ to $0.44 \%$. Sample L-B had the highest $\mathrm{C} / \mathrm{N}$ ratio of $19, \mathrm{~L}$ and $\mathrm{L}-\mathrm{R}$ had $\mathrm{C} / \mathrm{N}$ ratios of 15.68 and 14.6 , respectively.

Sample L-B had the fastest decomposition process when compared to samples L-R and L. Once the ideal thermophilic temperature was reached in sample L-B, the decomposition process occurred more rapidly due to the nutritional and bulking properties of the rice bran, thus accelerating the whole composting process. Visual observation (colour and physical appearances), indicated the sample L-B reached maturity at about 24 days, whereas the sample L-R reached maturity at 27 days and L had not reached maturity by day 30 
Table 1. The quality of compost after 30 days

\begin{tabular}{|c|c|c|c|}
\hline \multirow{2}{*}{ PARAMETER } & \multicolumn{3}{|c|}{ VARIATION } \\
\cline { 2 - 4 } & L & L-B & L-R \\
\hline C-Organic & 6.90 & 5.41 & 3.42 \\
\hline N-Total & 0.44 & 0.37 & 0.18 \\
\hline C/N Ratio & 15.68 & 14.60 & 19.00 \\
\hline P-Total & 0.65 & 0.63 & 0.54 \\
\hline K-Total & 0.20 & 0.16 & 0.22 \\
\hline Water content (\%) & 15.96 & 15.31 & 14.95 \\
\hline pH & 7.56 & 7.57 & 7.32 \\
\hline Temperature & 25 & 25 & 25 \\
\hline
\end{tabular}

\section{CONCLUSION}

Three different variations in the composting of leaves; composting of leaves only, leaves with rice bran and leaves with rumen content, were investigated. During the composting process, temperature and $\mathrm{pH}$ were monitored. The addition of rice bran optimised the composting process. The quality of the mature compost with regards to organic content, total $\mathrm{N}, \mathrm{C} / \mathrm{N}$ ratio, total $\mathrm{P}$ and total $\mathrm{K}$ were also examined. Physically, all the mature compost samples had similar appearance with brownish black colour and smelt like soil. The compost with rice bran added reached maturity in 24 days, while the compost with leaves only and addition of rumen contents required more time to reach maturity.

\section{References}

1. T.T.P. Nguyen, D. Zhu, N.P. Le, Habitat Int., 48 (2015)

2. M.K. Younes, Z.M. Nopiah, N.A. Basri, H.Basri, M.F. Abushammala, M.Y. Younes, Waste Manage. 55 (2016)

3. S. Suthar, P. Singh, Sustain. Cities Soc. 14 (2015)

4. A. Makan, Waste Manage. 42 (2015)

5. L.L.C. Guidoni, R.V. Marques, R.B. Moncks, F.T. Botelho, M.F. da Paz, L.B. Corrêa, É.K. Corrêa, J. Environ. Manage. 207 (2018)

6. K. Shrestha, , E.M. Adetutu, P. Shrestha, K.B. Walsh, K.M. Harrower, A.S. Ball, D.J. Midmore, Bioresource Technol. 102, 17 (2011)

7. K. Kato, N. Miura, Bioresource Technol. 99, 9 (2008) 